\title{
Job Satisfaction of Malaysian Nurses: A Causal Model
}

\author{
Yuen-Onn Choong*, Teck-Chai Lau, Thiam-Yong Kuek, Eng-Keong Lee \\ Universiti Tunku Abdul Rahman Malaysia, Malaysia \\ *choongyo@utar.edu.my
}

\begin{abstract}
Turnover intention is a challenging issue for most of the developed and developing countries. Past studies revealed that there were two common approaches to enhance nurses' retention. The first approach is focus on recruitment and selection activities as well as establishes more schools and colleges of nursing that will produce more nursing graduate. The second approach is to attract and retain more dedicated and quality professional nursing staff. Substantial studies have confirmed that job satisfaction as a major predictor of turnover intention. Therefore, this paper is mainly focus on identifying significant predictors of job satisfaction which will subsequently reduce turnover intention among staff nurses in Malaysia healthcare industry.
\end{abstract}

Keywords: Job Satisfaction, Turnover Intention, Leadership Style, Job Stress and Psychological Empowerment

\section{Introduction}

Turnover intention is a challenging issue in various industries. This is especially true for nursing industry, either the developed or developing countries such as United Stated of America, Canada, England, Scotland, Germany and Philippine (Aiken et al., 2001; Lu, While \& Barriball, 2005; Hayajneh, Abu AlRub, Athamneh \& Almakhzoomy, 2009). Among professions, nurses have higher turnover rates. High nursing turnover are likely lead to shortage of nursing staff and skillful and experienced nurses (O'Brien-Pallas, Murphy \& Shamian, 2006; Hunt, 2009). The global issue of nursing turnover has greatly negative impact on the healthcare organizations performance and profitability (Hunt, 2009). This is a difficult task for healthcare organization to retain highly trained and fully committed nursing staff to provide them good patient care knowledge (Hunt, 2009). Other than decreased quality of patient care, this phenomenal will also increase contingent staff costs, staffing costs, nurse turnover and absenteeism rates and loss of patients (Hunt, 2009). According to O'Brien-Pallas (2006) and Contino (2002), nursing turnover will cause high and unpredictable replacement costs. These unpredictable costs can be divided into direct costs and indirect costs. Direct costs include training cost, recruitment and selection costs, hiring costs and orientation day (Sullivan \& Decker, 1985). For indirect costs, there is promotion or transfer to other position within an organization, costs of trainer's time, reduces efficiency and advertising costs for replacement vacant position.

Research Problem: Malaysian Government has set a target to achieve a total of 174, 000 nurses by the year 2020, with citizens per nurse ratio of 1:200. Table 1 showed the total number of registered nursing personnel increased every year from 31, 129 in 2000 to 59, 375 nurses in 2010. The ratio improved as well, from 1:747 in 2000 to 1:410 in 2010. This shows that Malaysia has taken initiative to improve its healthcare industry (Ministry of Health Malaysia, 2012). However, the 2010 citizens per nurse ratio of 1:410 are still far away from the targeted citizens per nurse ratio which is 1:200. No doubt, there is still a shortage of nurses in Malaysia. Siew and Chitpakdee (2011) pointed out that professional nurses have migrated to other countries in every year. The attrition rate of nurses is approximately 400 per year. In addition, turnover rate has been increased dramatically from 400 nurses in 2005 to 1, 049 nurses in 2010 which is more than $50 \%$. From Table 1, the average growth rate in the past 10 years is around $8.36 \%$.If the growth rate increases steadily, the targeted number of nurses will be able to achieve by year 2020 . According to Barnett, Namasivayam and Narudin (2010) and Muniandi (2010), there is a rapid expansion of nurses' workforce in Malaysia which will "pose a threat to the long term stability of nurses' workforce and impact on the quality of patient care". In addition, this will also increase new nursing burnout and workforce attrition due to the reality job expectation (Bryant, 2005), work-related stress (Hayes et al., 2006), burnout (Leiter \& Maslach, 2009; Hayes et al., 2006), leadership style (Kleinman, 2004), etc. 
Table 1: Statistic for Total Number of Nurses and Ratio in Malaysia from 2000 to 2010

\begin{tabular}{ccccc}
\hline Years & $\begin{array}{c}\text { Total Number of } \\
\text { Nurses }\end{array}$ & $\begin{array}{c}\text { Growth Rate (\%) } \\
\text { (CY-PY/PY) X 100\% }\end{array}$ & Population & $\begin{array}{c}\text { Ratio (No. of citizens } \\
\text { per nurse) }\end{array}$ \\
\hline 2000 & 31,129 & Nil & $23,253,363$ & $1: 747$ \\
2001 & 33,295 & 6.96 & $23,805,925$ & $1: 715$ \\
2002 & 35,280 & 5.96 & $24,519,600$ & $1: 695$ \\
2003 & 36,784 & 4.26 & $25,049,904$ & $1: 681$ \\
2004 & 40,220 & 9.34 & $25,579,920$ & $1: 636$ \\
2005 & 44,120 & 9.70 & $26,119,040$ & $1: 592$ \\
2006 & 47,642 & 7.98 & $26,640,200$ & $1: 559$ \\
2007 & 48,916 & 2.67 & $27,173,600$ & $1: 556$ \\
2008 & 54,208 & 10.82 & $27,828,700$ & $1: 512$ \\
2009 & 59,375 & 9.53 & $28,306,700$ & $1: 477$ \\
2010 & 69,110 & 16.40 & $28,334,100$ & $1: 410$ \\
\hline
\end{tabular}

Note: CY - Current Year, PY - Previous Year, Source: Ministry of Health, Malaysia (2012)

Past studies has indicated two approaches to address the issues of turnover intention in order to prevent shortage of nursing staff (Leiter \& Maslach, 2009). The first approach is focus on recruitment and selection activities as well as establishes more schools and colleges of nursing that will produce more nursing graduate. This approach will help to offset the shortage of nursing in the short run (Siew \& Chitpakdee, 2011). The healthcare industry need to continuously play an active role in recruitment and hiring activities as the sources of problem are still unknown and unsolved. Although Malaysian government encourages and actively involved in established more schools and colleges that specialized in producing fresh and professional nursing graduate, unfortunately majority of fresh nursing graduate are not ready to commit themselves in the profession or the reality of nursing job is not within their expectation (Barnett, Namasivayam \& Narudin, 2010). Instead, they might decide to leave the organization or switch to other profession. This approach will incur high unpredictable replacement costs such as recruitment and selection costs, training costs, advertising costs and reduce efficiency. The second approach is to focus on retention which is to attract and retain more dedicated and quality professional nursing staff (Leiter \& Maslach, 2009). This can be done by providing fulfilling experience and sustainable careers to nurses. The human resource personnel and supervisors for healthcare organization should ensure that nurses are satisfied with their job. After all, job satisfaction is one of the major predictor for turnover intention and retention in healthcare industry (Hayes et al., 2006; Larrabee, Janney, Ostrow, Withrow, Hobbs \& Burant, 2003). Leiter and Maslach (2009) stated that the second approach might be a better strategy as compared to the first approach. Retaining nurses will help to minimize the shortage of nursing throughout the world in the long run. This can also maintain the quality of patient care at minimum costs.

Research Objective: The first approach is simpler to practice yet it is very costly and only effective in the short run. For the second approach, it is more challenging, less costly and enduring. Hence, this is advisable to adopt second approach (Leiter \& Maslach, 2009). According to Toni (2007), Coomber and Barriball (2007), Hayes et al. (2006) and Larrabee et al. (2003), job satisfaction has been examined as a major predictor to intent to stay or reducing turnover intention in most of countries healthcare industry. Employees who felt dissatisfied with their job will try to find another job in other companies, switch to other jobs within an organization or switch to other profession. Job satisfaction has pointed out as first related to turnover intention and intent to stay (Cohen \& Golan, 2007). Understanding the antecedents of job satisfaction is keys to enhancing morale within the nursing profession and minimizes the issues of turnover intention. Eventually, this will enable nursing industry to have enough workforces to support the demands of aging population (Muniandi, 2010). There are a number of determinants of job satisfaction which are related to turnover intention such as leadership style or supervision (Barnett, Namasivayam \& Narudin, 2010; Coomber and Barriball, 2007;Yin \& Yang, 2001; Fang, 2001), pay (Lephalala, 2006; Fang, 2001), interpersonal relationships with supervisors, co-workers and subordinates (Lephalala, 2006; Abreu \& Valle, 2000), heavy workload or work stress (Strachota, Normandin, O’Brien, Clary \&Krukow, 2003), working conditions (Lephalala, 2006), intrinsic factors such as work itself (Bluett, 2008; Hayes et al. 2006; Vetter, Felice \& Ingersoll, 2001), achievement (Yin \& Yang, 2002), recognition (Ernst, Franco, Messmer \& Gonzalez, 2004; Tzeng, 2002; Abreu \& Valle, 2000), responsibility (Lephalala, 2006; Kramer \& Schmalenberg, 2003; Laschinger, Shamian\& Thomson, 2001) and opportunity of promotion or career advancement (Strachota et al., 2003; Tzeng, 2002), psychological empowerment (Laschinger, Finengan, Shamian \& Wilk, 2004; Larrabee, 2003), individual factors (Hayes 
et al., 2006; Tzeng, 2002),alternative employment opportunity (Hayes et al., 2006; Strachota et al., 2003) and organizational commitment (Cohen \& Golan, 2007). Past studies had showed that major determinant of job satisfaction toward nurses' turnover intention tend to be different in different countries. According to Larrabee et al. (2003), job satisfaction is an important predictor of turnover intention and empowerment is a major factor of job satisfaction. While, past study has been found that leadership style is a major determinant in nurses' satisfaction (Lu, While \&Barriball, 2005). Bratt, Broome, Kelber and Lostocco (2000) stated that job stress and leadership are the most influential determinants of job satisfaction. In this paper, the antecedents for job satisfaction toward turnover intention namely; leadership style, psychological empowerment and job stress are included. Therefore, the main research objective is to examine the antecedents of job satisfaction among nurses of healthcare industry in Malaysia. This paper is mainly to test the relationship between the antecedents and job satisfaction in Malaysia healthcare industry.

Significance of the study: By conducting this study, it will enable Malaysian healthcare industry to have a better understanding on the relationship between antecedents and job satisfaction and subsequently on turnover intention. This research study will examine which predictors are highly related with job satisfaction in Malaysian healthcare industry. Hence, this will provide valuable insight to human resource personnel and nurse supervisors on how to address the problem of high turnover intention and nursing shortage.

\section{Literature Review}

\section{Definition of the Terms}

Leadership Style: Leadership style can be defined as the process of ability to influence, motivate and enable others in an organizational culture in order to ensure the effectiveness of the organizations of which they are members (McShane \& Von Glinow, 2010). Generally, there are two types of leadership namely transformational and transactional leadership style. Transformational leadership style is a leader that involves consideration intellectual stimulation and changing the organization to fit the environment. Transformational leader can be identified as change agent of the company. They have the ability to transform the employees' attitudes, behaviors and values by displaying favorable, influential and supportive interactions (McShane \& Von Glinow, 2010). They are motivated, willing to share vision of the organization, providing employees useful direction in attaining company objective and openness to employees' inputs and ideas. For transactional leadership style, the leader are achieving current objective more efficiently as they focus on day to day operations (McShane \& Von Glinow, 2010). Transactional leader are more active and utilize their transactions on an exchange of rewards and benefits to employees job performance and achievement. They also will ensure employees have necessary resources to complete their daily task and attaining their target setting. The leader may utilize the leadership techniques with staff either passive or active management by exceptions (Colquitt, Lepine \& Wesson, 2009). Active management by exception refer to the leader arrange to monitor mistakes and error actively and takes corrective action when there is required. For passive management by exception, this is referring to the leader wait for the mistakes and errors occur and then take corrective action when there is necessary.

Psychological Empowerment: Psychological empowerment can be defined as a process of increasing employee's feelings of self-efficacy within an organization (Conger \& Kanungo, 1988). Spreitzer (1995) has identified four empowerment cognitions namely: meaning, impact, competence and selfdetermination.

Job Stress: Job stress can be resulted from work overload (Yin \& Yang, 2001) and Inflexible work scheduling (Cartledge, 2001; Shader, Broome, Broome, West \& Nash, 2001). Flexible working hours will provide a sense of autonomy and the ability to fulfill their family responsibility. This is also to balance both of their work and family or life especially for women who have children or retired parents. Job stress is defined as "a pattern of emotional states and physiological reactions occurring in situations where individuals perceive threats from the environment beyond their ability to manage" (Fang, 2001; McShane\& Von Glinow, 2010). 


\section{Relationships between Antecedents and Job Satisfaction}

Leadership Style and Job Satisfaction: Kleinman (2004) stated that an effective leader demonstrate both transformational and transactional leadership characteristic. This both types of leadership behaviors are considered as positive forms of leadership. If he or she is said to be a good manager, then he or she will exhibit both types of leadership behaviors (Bass \& Avolio, 2000).It is also a key factor in staff nurse job satisfaction and promotes their retention (Lu, While \&Barriball, 2005; Kleinman, 2004).Larrabee et al. (2003) tested that leadership has indirect association with nursing turnover intention in United Stated Healthcare industry. They also found that transformation leadership style is related to psychological empowerment which in turn leads to enhancement of job satisfaction. Subsequently, this will reduce turnover intention of nurses. Kleinman (2004) has conducted a study to test the relationship between specific managerial leadership behavior and staff nurse retention. Kleinman found that when the nurse manager demonstrates a higher mean frequency of transformation leadership behaviors, the staff nurse did not concur with their manager. However, Kleinman study indicated that active management by exception behaviors for transactional leadership style is strongly related with turnover. However, the study of Colquitt, Lepine and Wesson (2009) stated that transformation leadership is directly increased job satisfaction. There is another study shown that there is no association between leadership style and job satisfaction and intention to leave in a nursing company (Tzeng, 2002).

Hypothesis 1: There is a significant negative relationship between leadership style and job satisfaction among nurses in Malaysia healthcare industry.

Psychological Empowerment and Job Satisfaction: The study of Laschinger, Finengan, Shamian and Wilk (2001) postulated that empowerment are significantly predict trust in management, perceived control over nursing, organizational commitment, job satisfaction and lower levels of job stress. Larrabee et al. (2003) indicated that psychological empowerment is one of important predictor of job satisfaction. This is subsequently reducing turnover intention (Laschinger et al., 2004). Structural equation modeling analyses were shown the hypothesized model is in a good fit with a total randomly selected staff nurses are 185 samples. However, structural empowerment had a direct impact on job satisfaction but not to psychological empowerment. This might due to the limitations of the study as this study is adopting longitudinal study method. Laschingers and colleague have faced some common problem which is loss to follow-up and history effect. The size of samples between time 1 (original sample) and time 2 (final sample) was different with a three years gap. They found that majority of staff nurses do not change their work unit over the past three year period. However, when time pass through, there is some additional factors might influenced the staff nurses job satisfaction in Ontario. Hence, there is no significant relationship between psychological empowerment and job satisfaction among staff nurses in Ontario healthcare industry.

Hypothesis 2: There is a significant negative relationship between psychological empowerment and job satisfaction among nurses in Malaysia healthcare industry.

Job Stress and Job Satisfaction: A number of studies have consistently shown that stress as a major determinant of job satisfaction and to turnover intention of staff nurses in various countries such as United State, Singapore, Taiwan and United Kingdom (Coober \&Barriball, 2007; Yin \& Yang, 2002; Fang, 2001; Shader et al., 2001). There are some common stressor in health care industry are work over-load (Strachota et al., 2003), inflexible work schedule or work-life balance (Hayes et al., 2006; Tzeng, 2002) and unnecessary overtime (Mateus, 2007). Fang (2001) has conducted a study among 180 staff nurses in a large Singapore hospital. She found that job stress is directly and significant effect throughout different stages in turnover development. She also claimed that job satisfaction is not playing a mediating role in between job stress and turnover intention among staff nurses in healthcare industry. Another study has postulated opposite result which job stress is negatively related to job satisfaction. Subsequently, this will have further influential on nurses' turnover intention (Yin \& Yang, 2001). Due to shortage of nursing, this has been increased the workload per nurse. When there is burden of high workload, then, there will be more staff nurses decide to leave the profession or organization. The situation of nursing shortage will become even worst. Therefore, it will be useful to examine how stress impact on job satisfaction among staff nurses in Malaysia health care industry.

Hypothesis 3: There is a significant positive relationship between job stress and job satisfaction among nurses in Malaysia healthcare industry. 


\section{Proposed Conceptual Framework and Hypotheses Development}

This paper proposes to identify the relationship between factors and job satisfaction among staff nurses in healthcare industry. Based on the discussion presented in the literature review, leadership style, psychological empowerment and job stress affect job satisfaction. Based on the above discussion, the research framework is constructed and presented in Figure 1.

Figure 1: The Proposed Conceptual Framework for Present Research Study

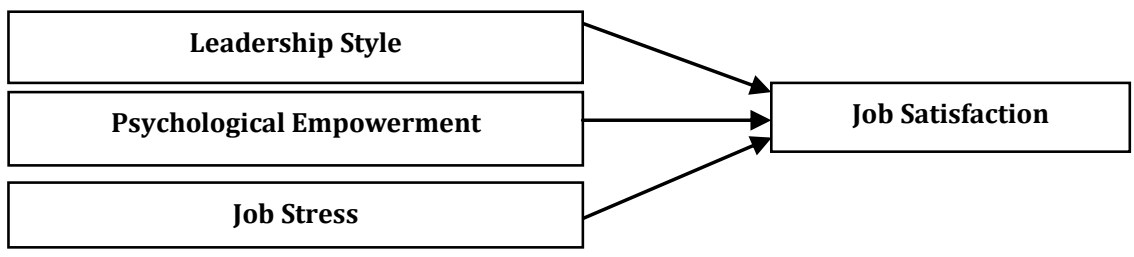

The study proposed a list of hypotheses which concerning the staff nurses in Malaysian healthcare industry:

Hypothesis 1: There is a significant negative relationship between leadership style and job satisfaction among nurses in Malaysia healthcare industry.

Hypothesis 2: There is a significant negative relationship between psychological empowerment and job satisfaction among nurses in Malaysia healthcare industry.

Hypothesis 3: There is a significant positive relationship between job stress and job satisfaction among nurses in Malaysian healthcare industry.

Hypothesis 4: Leadership style, psychological empowerment and job stress are significant contribute to job satisfaction among nurses in Malaysia healthcare industry.

\section{Conclusion}

The objective of this paper is to examine the antecedents of job satisfaction among nurses in healthcare industry. Past studies have supported that there is a significant relationship of leadership style, psychological empowerment and job stress with job satisfaction. Eventually, this will reduce the nurses' turnover intention. By conducting this research study, it provides valuable information and knowledge to human resource personnel and nurses' supervisors. Since, this study also highlights the importance of the antecedents in order, this will enable healthcare industry management to emphasize the more important antecedents in order to retain nurses and reduce turnover intention in healthcare industry.

\section{References}

Abreu, E. C. \& Valle, M. M. (2000). Management principles of business management (10th ed.). Portugal: Mcgraw-Hill.

Aiken, L. H., Clarke, S. P., Sloane, D. M., Sochalski, J. A., Busse, R., Clarke, H. (2001). Nurses' reports on hospital care in five countries. Health Affairs, 20(3), 43-53.

Barnett, T., Namasivayam, P. \& Narudin, D. A. (2010). A critical review of the nursing shortage in Malaysia. International Council of Nurses, 2, 32-39.

Bass, B. \& Avolio, B. (2000). MLQ multifactor leadership questionnaire (2nd ed.). Redwood City; CA: MindGarden, Inc.

Bluett, L. (2008). Recruitment and rentention report: self-scheduling: facilitate, don't control. Nursing Management, 39(6), 12-54.

Bratt, M. M., Broome, M., Kelber, S. \& Lostocco, L. (2000). Influence of stress and nursing leadership on job satisfaction of pediatric intensive care unit nurses. American Journal of Critical Care, 9(5), 307317.

Bryant, R. (2005). The global nursing review initiative. Regulation, Roles and Competency Development. International Council of Nurses, Geneva, 2(1).

Cartledge, S. J. (2001). Factors influencing the turnover of intensive care nurses. Intensive and Critical Care Nursing, 17(6), 348-355. 
Cohen, A. \& Golan, R. (2007). Predicting absenteeism and turnover intentions by past absenteeism and work attitudes. Career Development International, 12(5), 416-432.

Colquitt, J. A., Lepine, J. A. \& Wesson, M. J. (2009). Organizational behavior: improving performance and commitment in the workplace. New York: McGraw-Hill.

Conger, J. A. \& Kanungo, R. N. (1988). The empowerment process: integration theory and practice. Academy of Management Journal, 13(3), 471-482.

Contino, D. (2002). How to slash costly turnover. Nursing Management, 33, 10-13.

Coomber, B. \& Barriball, K. L. (2007). Impact of job satisfaction components on intent to leave and turnover for hospital-based nurses: a review of the research literature. International Journal of Nursing Studies, 44, 297-314.

Ernst, M. E., Franco, M., Messmer, P. R. \& Gonzalez, J. L. (2004). Nurses' job satisfaction stress and recognition in a paediatric setting. Paediatric Nursing, 30(3), 219-227.

Fang, Y. (2001). Turnover propensity and its causes among Singapore nurses: an empirical study. International Journal of Human Resource Management, 12(5), 859-871.

Hayajneh, Y. A., AbuAlRub, R. F., Athamneh, A. Z. \& Almakhzoomy, I. K. (2009). Turnover rate among registered nurses in Jordanian hospital: an exploratory study. International Journal of Nursing Practice, 15, 303-310.

Hayes, L. J., O'Brien-Pallas, L., Duffield, C., Shamian, J., Buchan, J. \& Hughes, F. (2006). Nurse turnover: a literature review. International Journal of Nursing Studies, 43, 237-263.

Hunt, S. T. (2009). Nursing turnover: costs, causes and solutions. San Diego: SuccessFactors Inc.

Kleinman, C. (2004). The relationship between managerial leadership behaviors and staff nurse retention. Research and Perspectives on Healthcare, 84(4).

Larrebee, J. H., Janney, M. A., Ostrow, C. L., Withrow, M. L., Hobbs Jr., G. R. \& Burant, C. (2003). Predicting registered nurse job satisfaction and intent to leave. Journal of Nursing Administration, 33(5), 271-283.

Laschinger, H. K., Finengan, J., Shamian, J. \& Wilk, P. (2001). Impact of structural and psychological empowerment on job strain in nursing work settings: expanding Kanter's model. Journal of Nursing Administration, 31, 260-272.

Laschinger, H. K., Finengan, J., Shamian, J. \& Wilk, P. (2004). A longitidinal analysis of the impact of workplace: empowerment on work satisfaction. Journal of Organizational Behavior, 25, 527-545.

Laschinger, H. K., Finengen, J. \& Thomson, D. (2001). Impact of magnet hospital characteristics on nurses' perceptions of trust, burnout, quality of care, and work satisfaction. Nursing Economics, 19(5), 202-219.

Leiter, M. P. \& Maslach, C. (2009). Nurse turnover: the mediating role of burnout. Journal of Nursing Management, 17, 331-339.

Lephalala, R. P. (2006). Factors influecing nursing turnover in selected private hospital in England. University of South Africa.

Lu, H., While, A. E. \& Barriball, K. L. (2005). Job satisfaction among nurses: a literature review. International Journal of Nursing Studies, 42, 211-227.

Mateus, G. (2007). Reasons for high turnover of nursing professionals at public hospitals in Angola. South Africa: University of South Africa.

McShane, S. L. \& Glinow, M. A. (2010). Organizational behavior: emergence knowledge and practice for the real world (5th ed.). New York: McGraw-Hill/Irwin.

Ministry of Health, Malaysia. (2012). Retrieved August 8, 2012, from Kementerian Kesihatan Malaysia: http://www.moh.gov.my/

Morell, K., Clarke, J. \& Wilkinson, A. (2001). Unweaving leaving: the use of models in management of employees turnover. International Journal of Management Reviews, 3, 353-354.

Muniandi, T. S. (2010). Leaderhip styles and job satisfaction among nurses. Kedah, Malaysia: University Utara Malaysia.

O’Brien-Pallas L, Murphy, G. J. S. (2006). Retrieved from Canadian Nursing Turnover Study: http://www.chsrf.ca/research_in_progress $\backslash$ linda

Shader, K., Broome, M., Broome, C., West, M. \& Nash, M. (2001). Factors influencing satisfaction and anticipated turnover for nurses in an academic medical centre. Journal of Nursing Administration, 31(4), 210-216.

Siew, P. L. \& Chitpakdee, B. C. (2011). Factors predicting organizational commitment among nurses in state hospital, Malaysia. The International Medical Journal Malaysia, 10(2), 21-28.

Spreitzer, G. M. (1995). Psychological empowerment in the workplace: dimensions, measurement and validation. Academy of Management Journal, 38(5), 1442-1465. 
Strachota, E., Normandin, P., O'Brien, N., Clary, M. \& Krukow, B. (2003). Reasons registered nurses leave or change employment status. Journal of Nursing Administration, 33(2), 111-117.

Sullivan, E. J. \& Decker, P. J. (1985). Effective management in nursing. California: Addison-Wesley Publishing Company.

Toni, G. N. (2007). Accelerated staff turnover among professional nurses at a district hospital. Nelson Mandela Metropolitan University.

Tzeng, H. M. (2002). The influence of nurses' working motivation and job satisfaction on intention to quit: an empirical investigation in Taiwan. International Journal of Nursing Studies, 39(8), 867-878.

Vetter, E., Felice, L. D. \& Ingersoll, G. L. (2001). Management, self-scheduling and staff incentives: meeting patient care needs in a neonatal intensive care unit. Health Care Management Review, 21(4), 5259.

Yin, J. T. \& Yang, K. A. (2002). Nursing turnover in Taiwan: a meta-analysis of related factors. International Journal of Nursing Studies, 39(6), 573-581. 